DOI: https://doi.org/10.47264/idea.lassij/4.2.22

Vol. 4, No. 2, (July-December 2020): 278-293

Research Article

URL: https://www.ideapublishers.org/index.php/lassij

\title{
Great Water Wall in South China Sea: Maritime Designs of China under Mahan's Theory of Sea Power
}

\author{
Tatheer Zahra Sherazi ${ }^{1}$, Arif Khan ${ }^{2}$ \& Hashmat Ullah Khan*3
}

1. Department of Politics \& International Relations, International Islamic University, Islamabad, Pakistan.

2. Department of Political Science, Faculty of Social Sciences, University of Buner, Sowari, Pakistan.

3. School of International and Public Affairs, Jilin University, Changchun, Jilin, China.

Published: December 30, 2020

\begin{abstract}
Seas play a vital role in shaping and reshaping the course of regional and global politics, from developing empires to new global orders. Virtually 80 percent of China's trade resources passes through the Seas and mostly by South China Sea. So, it has initiated developments in South China Sea, from building artificial island, light houses to air strips to secure its trade routes. The aim of the study is to investigate the assumptions that China is building a 'sand wall' or 'water wall' like great wall to secure its maritime trade. Descriptive, analytical approach has been adopted to study the marvel. Mahan's theory of Sea power has been applied to quantify the developments made by China. The study concludes that China is striving for naval supremacy as per Mahan's theory along with synthesis of Mao's 'Active Defence.' Hence peaceful and integrated strategies are required to minimize the implications of disruption of seaborne trade.
\end{abstract}

Keywords: Rise of China, Water Wall, South China Sea, Sea Power, Maritime Power, Maritime Strategy, Maritime Policy, Seaborne Trade.

\section{Introduction}

Throughout the history, the seas around China have been as crucial as the mainland areas, for commercial as well as social interactions. In this regard, the South China Sea has always remained a significant maritime route of interaction between South Asia, South East Asia and South West. Currently, however, it is sprouting in China's foreign policy as a 'core interest,' 'an area of a national interest' and as a 'historical part of China.' With vivid gages of power, China is certainly witnessed to be taking the lead in all disciplines of national and international growth. Regarding the South China Sea, a large portion of the Sea divided in the form of two island chains namely Spratly and Paracels. Both island chains have been declared as the "core national interest' by China - a claim which has been strengthened by constructing artificial islands and making other strategic developments on those islands. The objective of the study is to investigate the geostrategic and economic significance of South China Sea as an 'Integral part' of China. Besides that, to probe into the details of developments made by China in general and with special reference to South China Sea. Further suggestions for the regional code of conduct and methods to attract other powers to delve in the matter. Following questions would be the core of the research like what is the status of South China sea and how China is making developments along South China Sea. Besides that, why China is so concerned for South China 
Sea. The purpose is to inquire what is Mahan's theory of sea power and how it is significant in context of rise of China. Meanwhile what is common between Mahan's theory of sea power and China's Maritime policy particularly in context of South China Sea.

This research is a significant contribution since it not only highlights the rise of China instead its evolving role in global leadership. Moreover, the application of Mahan's theory on China's maritime strategy is significant in context of its rise. China's maritime designs have been analysed in context of Mahan's theory of Sea Power. Besides this, ongoing study investigates the significance of the Sea in war and peace times along with its utility at national and global level. The study has been divided into four segments, its opening segment explores the brief introduction including its scope, correlation of China' rise, maritime strategy, and Mahan's Sea Power along with significant queries. Second segment deals with the methods and technologies employed to analyse the collected data. Third segment analyses the Mahan's theory of Sea power and its efficacy that how the Sea borne trade and the naval supremacy are interlinked with the purpose of navies is to exert control over common lanes of Sea communications. The Last segment outlines the core tenets of China's maritime strategy. Meanwhile it also articulates the correlation of Mahan's theory of Sea Power and China' maritime strategy.

\section{Literature Review}

Fang (2015 analyses China's economic growth with well-documented introduction and other developmental factors that raised the living standard of the people. He also explains different trends of economic development, the role of various sectors, challenges, and opportunities to achieve the goal of moving from a middle income to rich income country. Thus, he illustrates the whole journey to obtain sustainable growth $(\mathrm{Ca}, 2015)$. The author documents the Chinese economy in a pragmatic way by explaining its all difficulties especially the economic reforms and other initiatives taken to improve the economy respectively. As a result of these reforms since 1978 onwards, China has transformed itself from a centrally planned economy to an emerging global market economy with impressive economic growth. He mentions an economic survey conducted by World Bank that during 1952 and 1981, China was at 0.5 percent that was almost a quarter of the ordinary growth rate of the other 19 developing nations. The writer justifies with the miracle formula for the Chinese economic growth that was based on reforms made at different levels in three phases that are from late 1970s to early 1980s; from 1980s to early 1990s; and from late 1990s onwards. According to Unsay (2013) since 1990s 'China's re-engagement with the global political economy has shaken the global community' and generated a debate about the role of China in world economy and in the global governance.

Dooley (2012) makes a powerful analysis of China 's naval strategy. According to him, Chinese ambition to be the maritime power is not a new agenda; rather, it goes back to the time of Zheng He. Later, the Ming Dynasty withdrew from the Sea and China made its focus on 'Continental' interests. In the present time, China's strive for maritime power can be understood by its growing merchant marine, rise in shipbuilding market, and efforts to equip the land with great naval capabilities. In this context, the analyst raises many questions regarding the grand strategy of being maritime power and tries to answer those questions with a conclusion that China must go a long way to be a great maritime power but before becoming so, it must prove its soft power as well. However, the way China is showing its devotion, determination, and sound approach, it would not be a long journey. Different theories can be put to test China's capabilities and intensions. Within the context of peaceful rise, this is an 
excellent analysis of naval modernization to meet the new needs of the time. However, some aggressive naval steps particularly in South China Sea cannot be taken as part of peaceful rise.

The security and political dimensions of South China Sea with all the technical themes like marine scientific research, historic claims, navigation regimes, regional common heritage, use of oceans. In this edited book, different writers from diverse backgrounds have given their views on different dimensions of the Sea related issues generally while regarding South China Sea in particular (Shicun \& Valencia, 2016). Tønnesson (2015) investigates South China Sea which has gotten fascination since 2009 when different clashes over drilling, fishing, naval exercises, started to occur in regions involving China, Philippine, Vietnam. Moreover, he claims that although China is rising and adopting aggressive stances occasionally, but after all, it will go with negotiations over the conflict under international law, which otherwise could hinder it to take further moves to develop. Further he introduces the interesting geopolitical notion that maritime territorial disputes are intrinsically less likely to lead to war than disputes over land borders. However, he ignores the other economic and political factors that are tremendous hindrances in dealing with this issue.

Song and Sou (2015, July) in their edited work collect all the well-known names on the maritime aggression and the resulting global concerns to take their views on the different dimensions of the Sea and particularly about its legal position on different chains of islands of Paracels and Spartly. Further suggestions for the regional code of conduct and methods to resolve the conflict have been discussed by security specialists, lawyers, military officers and people from academics and research from America, Europe and Taiwan. As South China Sea is a significant and current issues, most of the literature covering all dimensions is in edited version which is a result of the conference on the dimensions of the Sea. In this regard, Beckman et al. (2013) with other co-authors have edited a book based on the deposits of resources and then emphasized over the improvement of the nature of the issue and the efforts to settle the issue. According to Hayton, China's growing power has put the world in a turbulent state. For many decades, this region was smooth and making adjustments with their domestic as well as other bilateral issues. However, currently, the rise of China especially its policies towards South China Sea are making its neighbours worrisome. The author makes more focus on its historical claims and recent significance of South China Sea that the one that control this Sea controls the access between Europe, the Middle East, South Asia, and the Pacific.

Kaplan (2014) a strategist, explains the dynamics of global power change which is taking its shift from Europe to Asia. South China Sea is also emerging as a focal point with several billion barrels, an estimated nine hundred trillion cubic feet of natural gas. Kaplan interprets America's interests in Asia in the context of an increasingly assertive China. He explains how the region's unique geography fosters the growth of navies but also hinders aggression. He draws a striking parallel between China's quest for hegemony in the South China Sea and the United States' imperial adventure in the Caribbean more than a century ago. Despite being a good study, there is a need to investigate other aspects like economy and other geographic factors of the region for possessing the Sea and to control the Sea are not the sole indicator of power. Kim (1998) makes an excellent description of China's stance towards the growing global concerns and fully justifies the territorial rights of China over South China Sea as part of natural sovereignty as maritime power. She claims that the urge for recent position on South China Sea has been taken as a safe side due to certain domestic reasons. According to her, under the hegemonic designs, China's recent policy has different meaning so there is a need to analyse the intentions working under the present foreign policy and its different role taken place within region and outside. 
Kurlantzick (2006) views that China's rising status can be taken on a rule like the Western Europe rise during the $17^{\text {th }}$ century, or the US rise in the beginning of the $20^{\text {th }}$ century. In its rise, China's history, and culture play an important role through the unity drive and restoration of traditional influence among its neighbours. Beside this, the US key interests, impact of China's policies on these interests with different policy implications are also discussed. Currently, it is emphasized that the US should renew its ad hoc, episodic, and reactive policies towards China and must work with allies to wage a war against any terror in the region (Kurlantzick, 2006). The South China Sea has been considered as the second busiest shipping lane of the world and the habitation of huge energy resources. Thus, it is crucial to know what would be its future significance from energy and geostrategic point of view. In a transformed geopolitical environment, it is very substantial with enough material on the status of South China Sea with the interests of claimant states vis-a-vis the Sea and the role of Association of South East Asian Nations (ASEAN) in dealing with this issue.

There are two worldviews regarding the rise of China which have extreme interpretations; one describes, explains, and evaluates China into a threat while other advocates China as a peaceful country with pacific development. There are few facts needed to be considered that China is an economic giant with a huge population of 1.4 million out of total world population of 7.6 million, with an enormous potential of growth. Acceleration of growth within last three decades and expansion of Chinese trade in last decade has paved way for many future predictions. China's whole structure of growth and trade is dependent on two things; one is supply of energy resources while second is the supply of furnished goods to the other regions, these two things are core of the Chinese economy. One value which is highly crucial in China's economic success is the role of surrounding seas and particularly the South China Sea. China is heavily dependent on South China Sea for its trade, around 42\% of China's energy imports pass through South China Sea maritime route while manufactured goods of worth $\$ 5$ trillion to the other regions annually (Fensom, 2016, July). So South China Sea is highly significant for the growth and prosperity of Chinese economy. To protect the trade, it is necessary for China to safeguard the maritime routes passing through the South China Sea. Keeping this in mind, China is adopting various means within South China from claims on major portion of the Sea to various installations on the Sea, solidifying its claims. Besides the trade and energy supply, other geostrategic dynamics are also involved in so much emphasized claims, regarding the rise and fall of the states, how sea routes play a timeless role in country's strengthening, as per the Mahan's theory of the Sea power which describes, explains, and finally predicts about the status of the states who possess the seas as a 'high way' a 'common wide' (Mahan, 1905).

\section{Materials and Methods}

This study is descriptive, analytical, and explanatory is in nature where available data has been analysed, and evaluated critically. In the existing research, qualitative research method is applied for collecting and analysing the primary as well secondary data. Besides that, rise of China has been analysed under the umbrella of Mahan's theory of sea power. Rise of China has been investigated while taking a detailed account of its growth and growing patterns. Multiple primary and secondary sources have been consulted to get the conceptual underpinnings. Primary data is consisted on white papers of China, along with the policy statements, congressional agendas, and other unclassified official documents. While secondary data is consisted of articles, journal articles newspapers, academic reports published by academic institutions, news agencies and government institutions. The application of Mahan's 
theory of Sea power was quite challenging because of absence of China clear naval policy and strategy of peaceful development however these limitations were overcome by analysing its overall policy of development within South China Sea. This research is valuable for researchers as it carries the core of China's growth, global initiatives, and the role to be played by China.

\section{The Mahan's Sea Power Theory}

The Sea Power theory by Alfred Mahan suggests three requirements for great power: production, shipping, and colonies. According to Mahan, the above mentioned three requisites are significant as far as the national power is concerned. Maritime commerce is vital for the economic prosperity of a nation and hence for national wealth. Mahan strongly emphasizes that Sea power is the key of global predominance (King, 1990, April). He justifies his ideas by giving the example of the British Empire that it was the Sea power which led the Britain to be the Great Empire. According to Mahan, a state with a Sea has a great potential to dominate the world because the Sea itself has a massive potential to bring strength and prosperity to that state. Further, a state with a Sea is at an advantageous position as the Sea can perform many functions, some of which are as follows:

a) Sea as a 'well-worn trade route' for supplying trade and bringing the raw material at home

b) Sea is 'great' highway for transportation

c) Sea as a 'wide common' as a mean of communication to cover the all directions

While arguing about the requirements, he suggests six prerequisites conditions to acquire the three pillars. By engaging these conditions, many things can be materialized: geographical position, physical conformation, extent of territory, number of populations, character of the people, and character of the government.

\subsection{The Principles of the Sea Power Theory}

The Sea Power Theory is so deeply envisaged in the policies of China for which the whole state machinery is involved in pursuing the goals of six elements of a Sea power as mentioned by Mahan. Mahan's six principles can be clearly seen in the developing phases with significant other formalities for the purpose of achieving the great power (Mahan, 2011).

Figure 1: The Principles for Sea Power Theory

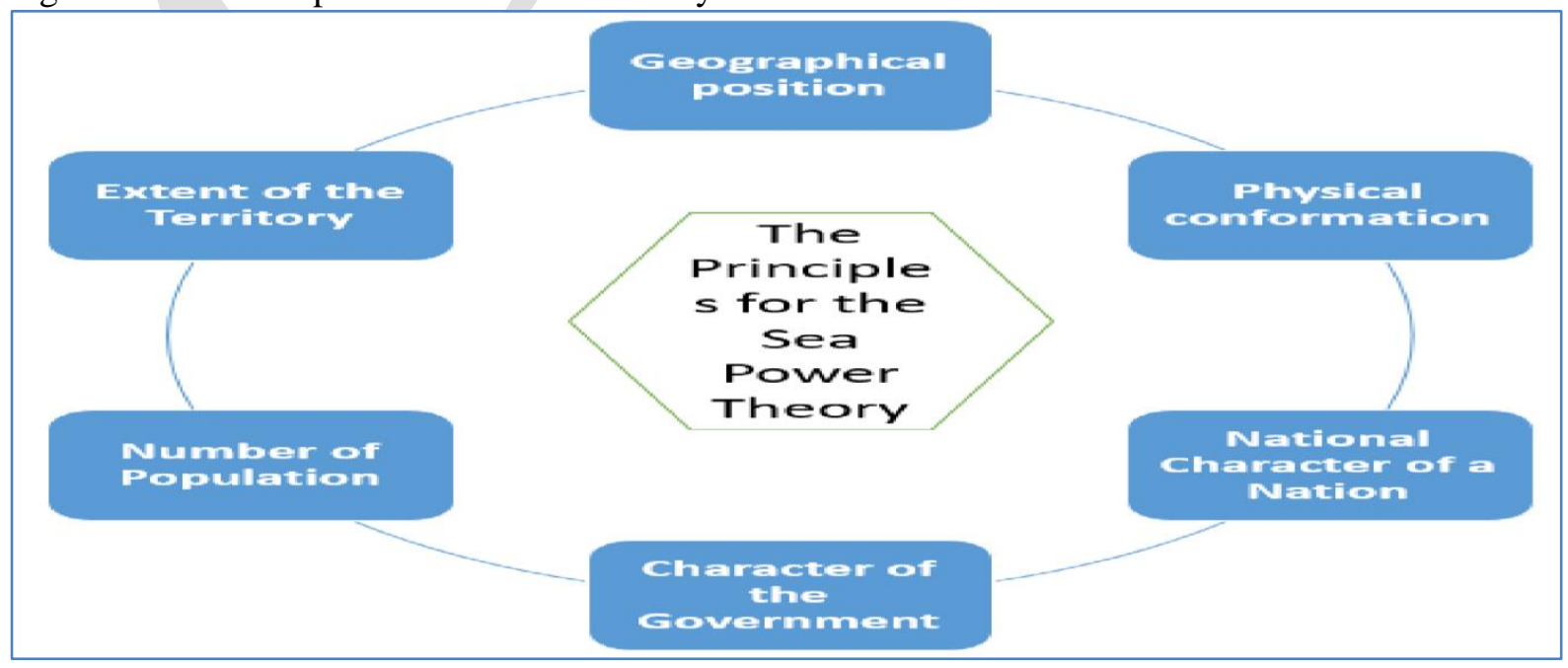




\subsubsection{Geographical Position}

By geographical position, Mahan refers to the location of a country that is safe from threats. According to him, to be an island state is to be at more advantageous position in defence as the Britain was and as US currently is protected by the Pacific and Atlantic Oceans. When China is analysed under Mahan's philosophy, it became obvious that it is located in the Asia Pacific with a huge coastline in its East and South as a distinct feature. China's location is highly significant for the Sea communications within the Pacific and Indian oceans connecting through various Sea like yellow, Sulu, East and the South China Sea. China, for futurist perspectives, is gradually increasing its influence in the Seas adjacent to its coastline. South China Sea is precisely significant for economic as well as geostrategic purposes as China is heavily dependent on the Seas for transportation of energy resources from Middle East. South China Sea is not only significant for China rather for other economic engines like Taiwan, South Korea, and Japan. Besides, the raw material, finished products to other parts of the globe are also transported from South China Sea. In this regard, China is making huge claims in South China Sea to secure its current and futurist influence in its neighbourhood and to secure the philosophy of First Island Chain (area from the Kamchatka Peninsula to the Malay Peninsula) as a military doctrine derived from the 'Island Chain Strategy' initiated during the end of Korean War in 1951 by John Foster Dulles which suggested containment and blockade by surrounding China. China has included the idea in its military strategy that is mainly based on 'three island chains' First Island China, Second Island China and Third Island Chain. First Island Chain is most significant for expansion of its influence in future politics and to meet its security needs.

According to the Chinese Military Doctrine, the First Island Chain is significant area to be secured and restricted from any foreign attack particularly restricted from American access. (Holmes, 2014). Not only restricted to access, however, the purpose is to build a capability for a pre-emptive attack against the adversaries. Determination is to not only make the borders secure but to extend the coastline to the territorial area for which China is competing with other states mainly with Vietnam and Philippine.

\subsubsection{Physical Conformation}

The physical conformation was the second element which refers to the Seaboard of any state; the greater the Seaboard, the more chances to interact with others. In other words, it is a greater opportunity to interact with other people of the world. Purposely, China is precisely following the principle to achieve higher aims; the broader the coastline, the more chances to interact with other states with huge communication through Sea. In this regard, China has engaged itself in the Sea based initiatives like B\&RI or BRI (Belt and Road Initiative) stretching from East Asia to Europe via connecting South Asia, Central Asia, and West Asia ultimately towards Europe and Americas. The connection made through the Sea is known as Road while the connection of states from China to Europe and America's via physical road is known as Belt. The South China Sea is the core to this whole initiative as all transportation will be carried out through this Sea.

\subsubsection{Extent of the Territory}

The extent of the territory means a territory which a country contains was the third element of 
Mahan "as regards the development of Sea power, it is not the total number of square miles which a country contains, but the length of the coast-line and the character of its harbours that are to be considered" (Mahan, 1949) as strategically it becomes harder for enemies to blockade the country which leads the communication of Sea traffic frictionless. With the use of Seas, technological advancements and economic growth, China can access the Globe from one end to the other through the B\&RI initiative. For the same purpose, China is developing different ports of least developed countries of Asia and Africa, to smooth the Sea traffic like in Thailand, Indonesia, Malaysia, Myanmar in East Asia while the Sri Lanka, Pakistan, and Bangladesh from South Asia and so on till the Piraeus, the Port of Greece. Different strategists have given the strategy of building ports as 'connecting chips in least developed areas' and the 'String of Pearls.' Along with the coastline and the territorial advantages, China has huge capacity, experience, and skills of building ports at home and globally. Out of world's top ten, China has six container ports of the world with huge capacity to trade in millions of volumes. In this regard, the Shanghai port in China is the World's largest container port with a capacity of 36.54 (Million TEU) (Lloyd's List of annual Top 100 Ports, 2017, June).

\subsubsection{Number of Population}

The number of population was the fourth element of Mahan's Sea power, particularly the number of populations involved in the Sea for their livelihood with higher skills and experiences in Sea faring. Chinese civilization is one of the ancient civilizations of the world that has lived in the cradle of Yantze and Yellow River. The growth of civilization in the areas of fishing for livelihood and migration from one area to another, mainly from India to China through the sea along with the sea expedients in various dynasties suggests the experience and skills of Chinese which is based on centuries of fishing, training, and other relevant aspects. In terms of experience and skills in the Sea trade and transportation along with the shipping industry, China is included in one of the top states of the world behind Greece and Japan with ownership of maximum ships (Greece marks the top position of the most ship owning nations in 2018, 2019).

Figure 2: Number of Population Involved in Sea (Chart 1-A)

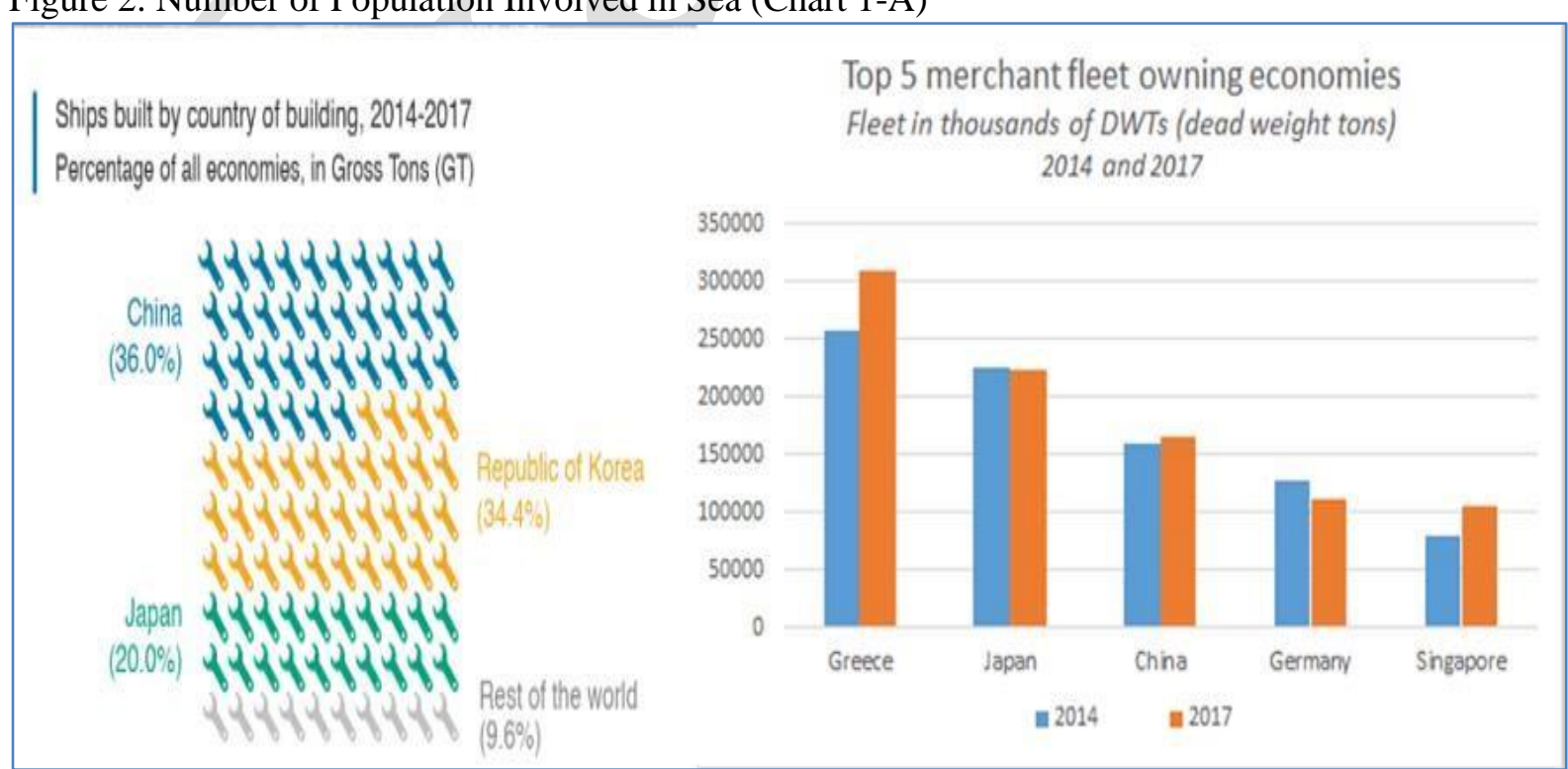

Source: Hoffmann (2010) 
Figure 2: Number of Population Involved in Sea (Chart 1-B)

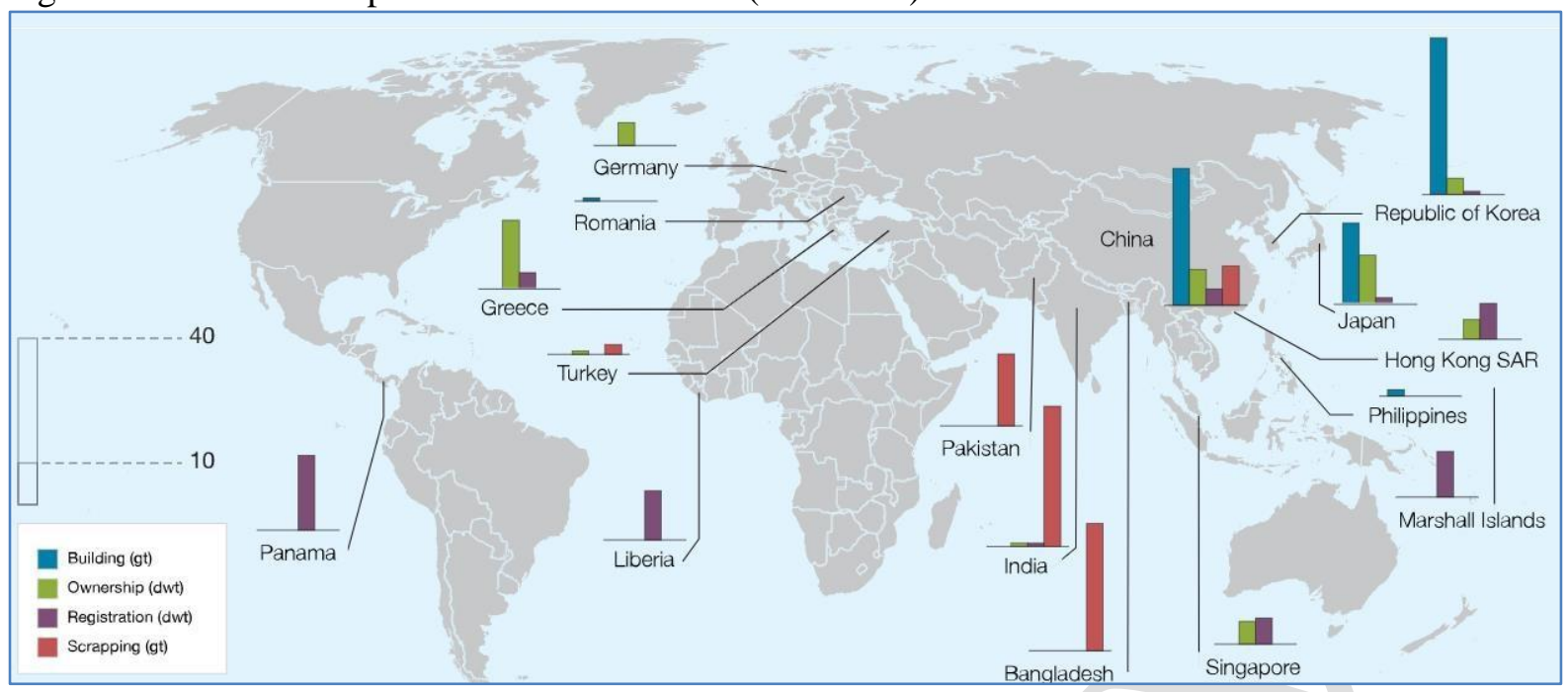

Source: Hoffmann, 2010

\subsubsection{National Character of a Nation}

According to Mahan, the states with seaborne trade aptitudes have greater capacities to grower and prosper. China is one of those nations that mainly depend on Sea and particularly on South China Sea for its trade which is the main pillar of economy and growth. Many estimates have been made about the trade and transportation in South China Sea. Below is the graph which demonstrates the production and consumption of oil by China showing the significance of South China Sea for the growing needs and consumption of oil:

Figure 3: China surpassed the US as the world's largest crude oil importer in 2017 \& 2018

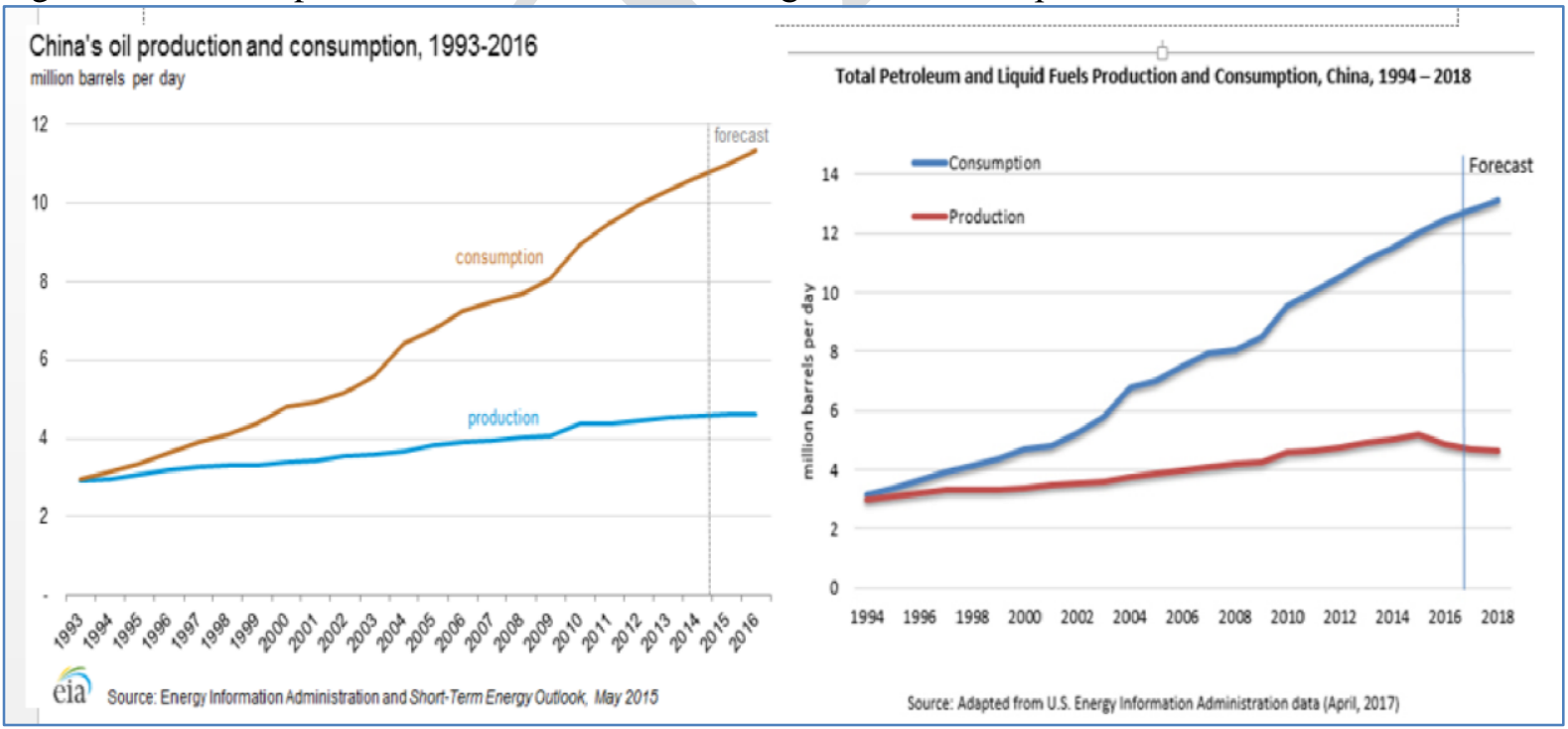

Source: US Energy Information Administration (2018, February)

Besides that, currently, a study has been conducted by the United Nations Conference on Trade and Development (UNCTAD) to examine the exact quantity of trade and transportation through the Sea based on the primary sources of trade. According to the United Nations 
Conference on Trade and Development (UNCTAD), approximately 80 percent of world's trade by volume and 70 percent by value are transported through Sea. Out of 60 percent approximately, 60 percent of the total trade passes through Asia, one third of the total trade of the world passes through South China Sea (Review of Maritime Transport, 2015). In other words, 26.6 percent of global trade passes through South China Sea and 20 percent of trade of Asia passes through South China Sea. For China, 60 percent of its total trade passes through South China Sea and 80 percent of energy resources for China are transported from the South China Sea. According to UNCTAD, 3.37 trillion trade passes through despite being 5.3 trillion. Total trade can be divided into various categories of imports and exports.

Figure 4: How much trade transits the South China Sea?

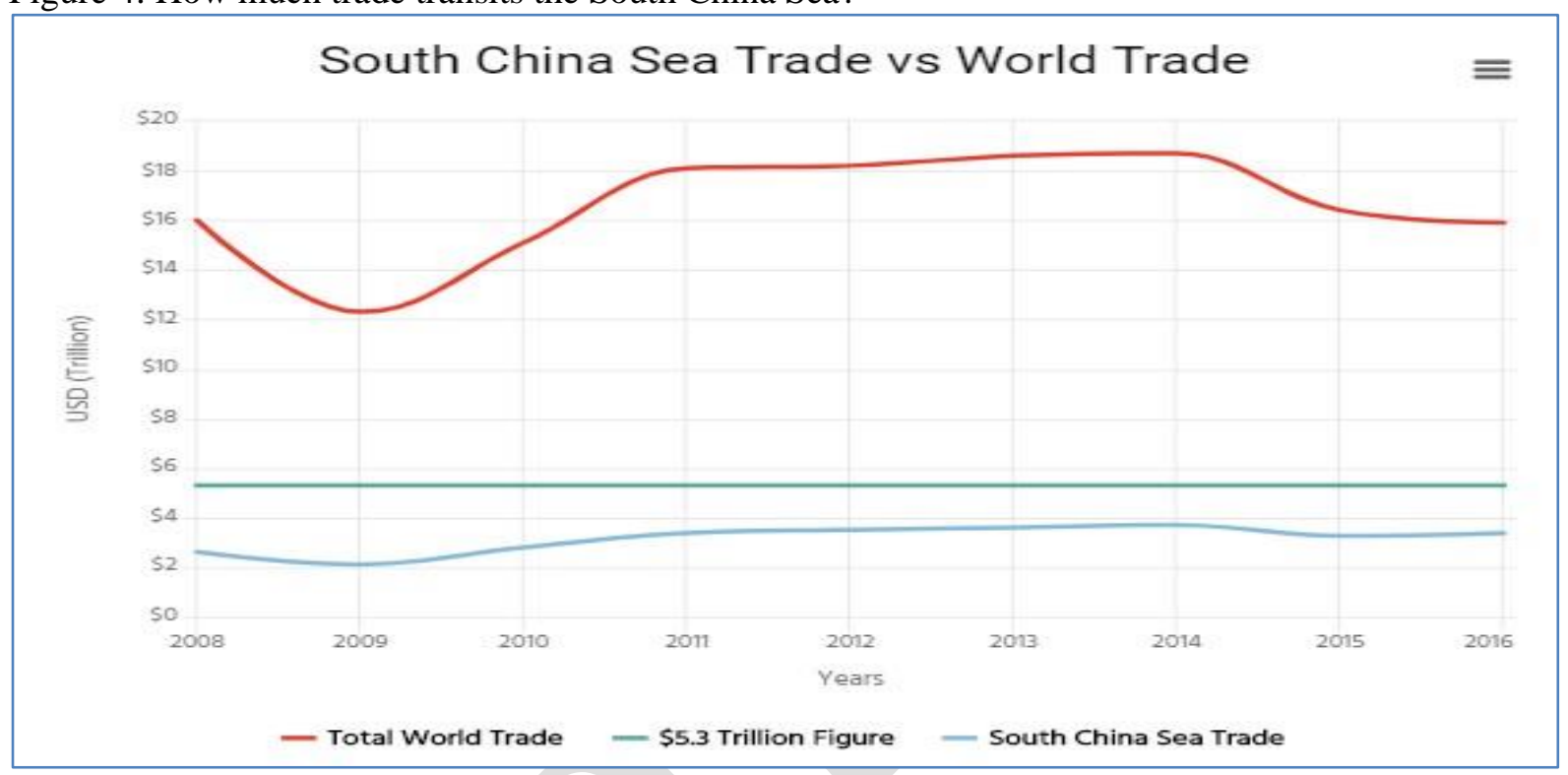

Source: CSIS (2017, October)

\subsubsection{Character of the Government}

In the sixth element of Mahan's theory, the government's over emphasis on the sea commerce and development of navy are directly proportional to a nation's strength and prosperity. If a government is interested in utilizing the sea and sea commerce, then it takes an advantageous position on a state which only depends on land for its economy and military. History has proved that sea power strategy can bring a state towards a secured position both in terms of trade and defence. As a test case, the US is an excellent example for having Atlantic and Pacific Oceans as the buffer zones for its defence and is beneficial for the communication of sea trade.

\section{China's Sea Power Model and Maritime Strategy}

Upon analyzing the Mahan's theory of Sea Power and China's recent moves within South China Sea suggest that China follows the essence of Mahan' theory of Sea power. China has integrated The Sea Power Theory into its foreign policy to achieve the economic, diplomatic, and military goals. Since 2013, China has initiated a policy of Belt \& Road Initiative which is the practical step towards the realization of Chinese goals. In general, theories and associated concepts are the products of a specific time to address certain situations, however, on basis of those theories many assumptions can be inferred suggesting guidelines for states relationships. Correspondingly, there is need to understand the actual maritime strategy of China. 
Figure 5: China Following the Sea Power Model

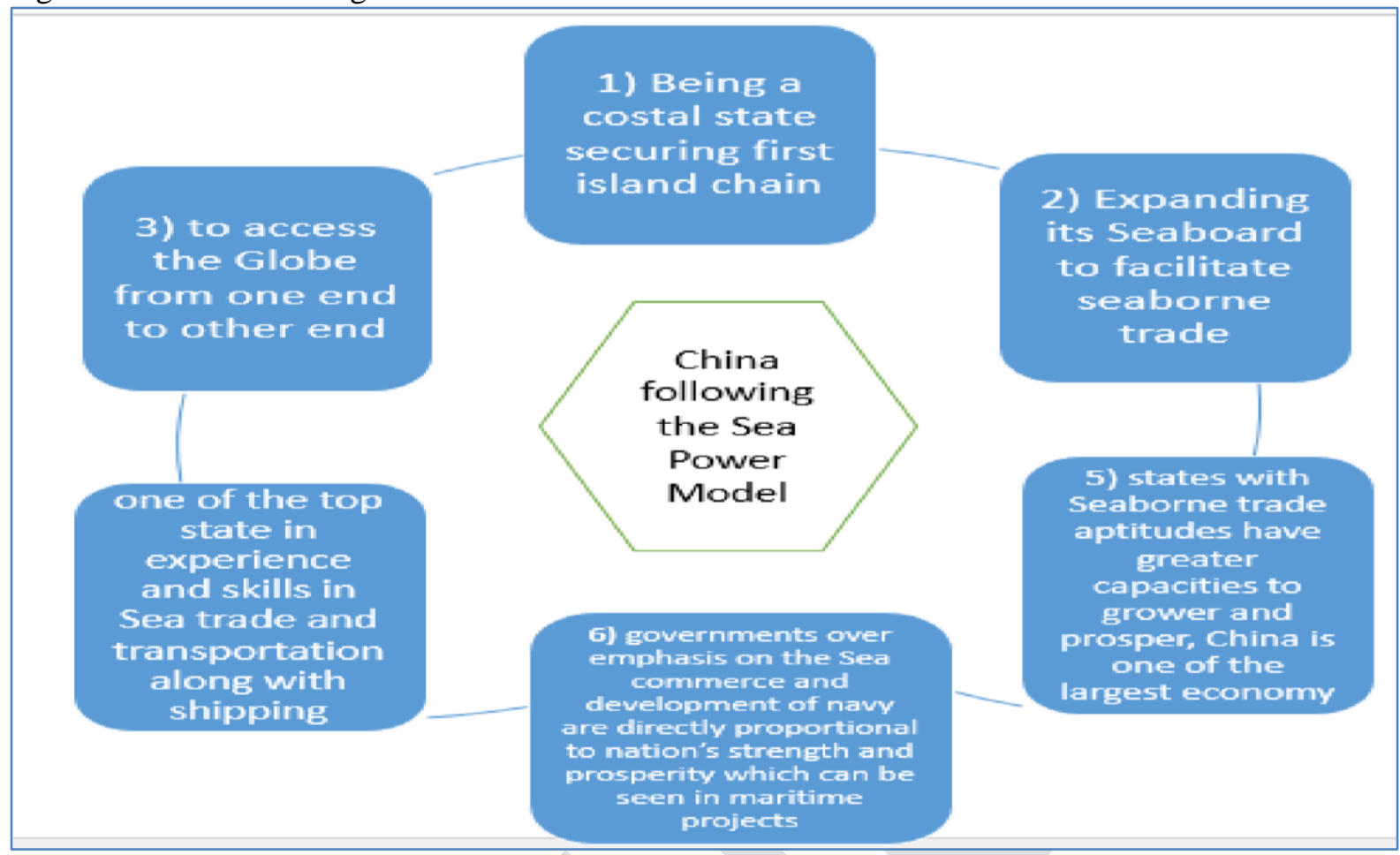

Source: Author's own contribution

China 's current policy of 'Pivot to Sea' is not a new one rather it can be traced back to the golden era of dynasties in China. During the period two maritime expeditions are considered most vital in describing the China's Pivot to Sea. One was made during Ming period by Zheng. He did eight voyages from 1405 AD to 1433 AD. These voyages are considered significant for diplomatic, political, and economic reasons because the ships were designed for seafaring purposes and not for the combat like the Europeans, whose purpose was to conquer the foreign lands along with the promotion of trade. In fact, the voyages were neither for the current notion of maritime trade nor for as per the Mahan view, for 'command of sea' rather for the connectivity of people and goods through using the sea faring channels (Derek, 2015). Zheng He's voyages have also symbolic significance of China that during the time China was not the land power but the sea power also which was displayed through these voyages.

China's current economic initiatives, with a particular focus on the mega commercial activities, keeping in view the worthy geostrategic position of China, being the pivot of the Earth, owning the longest coast, along with massive population, growing economy and subsequent to it the military build-up, suggests a journey towards the new era of the rise. The new era can be termed as the 'Renaissance of China,' particularly the renaissance of Chinese maritime slant, integrating with Mahan's approach of Sea Power. Apart from that, these initiatives have been taken to replace US as predominant power in Asia-Pacific region. Mahan theory of The Sea Power started to emerge gradually in the maritime strategy of China which has taken its rise in the form of 'Belt \& Road Initiative' (B\&RI), announced in 2013 however, it was mentioned in Chinese Intelligence Assessment Report (CIAR), released in May 2011 'Review: When Land Powers Look Seaward' a month later the conference at the US Naval Institute named 'When Land Powers Look Seaward (Erickson, 2011, April). In the report, apart from the appreciation for Mahan's work, a desire to transform itself from a mainland power to a maritime power was 
made to protect the commercial Sea lanes and free navigation of the commercial ships, and Sea power was taken as an important part of national prosperity and progress. Afterwards, Sea power strategy started to take its shape by announcement of 'Belt and Road Initiative' in 2013.

Mahanian school of thought is popular in China and most significant scholar of Mahanian school of thought is Professor Ni Lexiong who makes an analysis of competing claims of The Sea Power Theory and the globalization. Ni believes that China should not follow the traditional concept of The Sea Power Theory, as now globalization factor has revolutionized the institutions and existing institutions are not similar to Mahan's time. Now states and their interests are mutually interconnected, economically more dependent, and if a country wants to pursue power at Sea, it can only make it possible through cooperation not by a solo flight (Lexiong, Sea Power and China's Development, 2005). Further Ni says that China's on boarding with naval build up will hurt its long-term interests by alarming the existing global powers like the US as happened with the Germany during 19th century (Holmes, 2004). However, in the era of globalization, $\mathrm{Ni}$ discourages the concept of lasting peace that there is no lasting peace even for a pacific international order there will be a mechanism of force to keep the international system in order, hence China will be in need of a 'Muscular Navy' to play its role in the world navy and ultimately in the transition of international order. According to $\mathrm{Ni}$, states still exist in Hobbesion state of mind according to which they have to maintain a strong military power to pursue their self-interest so China has also the necessity to develop a to safeguard against the threats to its 'outward leaning economy' from other nations. Here Ni reminds the 'China's humiliation' from Japanese hands during 19th century in 1894-95, during which Qing Dynasty of China was defeated by a powerful Japanese battle fleet (Lexiong, Historical Necessity for the Transition from Land Power to Sea Power, 2007). So here lies the Mahan's principle that one who would control the Sea would control the war and ultimately would be in position to define the course of history. Upon a religious believe on power of Sea, Mahan was also known as the America's 'evangelist of Sea power' (Sprout), however his over emphasis on power of Sea and gun battleship has difficult to compare and low in relevance with current hi tech naval fleet.

Various scholars have their own viewpoints regarding China, its economic rise and future designs. According to realist school of thought China is building the sand wall subsequently to its rise which ultimately will result into reconstruction of new World Order, if not the World then regional order. At the same time neorealist claim that emergence of great powers will create a multipolar system which will challenge to secure peaceful balance of power. It is obvious that a bipolar system at least at sea is in making, even within region with power of two pools, on one side is China with a power on mainland while on the other side is the US with a power on Sea. Why China looking so emphatic for its maritime policy overall and South China Sea in particular? Here lies a grand strategy of China for maritime policy, most vital is the security threat, which engaged the Chinese policymakers for centuries. However, opening up the maritime trade strategy across the world can be taken in various ways, however the major one might be the collapse of Soviet Union, which has minimized the security threat to China's mainland which led to diplomatic success in resolving the border issues with the neighbouring states like Mongolia, Russia, North Korea, Vietnam and Central Asian states. There are assumptions that China with its growing economy is striving to become a Sea power without any fear to pursue its inland interests.

Primarily economic development is the key factor and the main driving force for its Seaward objectives.to secure the Sea lanes for a smooth transportation of goods, raw material and people 
is significant for China for its current as well as future development. For the same purpose China has initiated a diplomatic policy based on significance of Sea lanes and connectedness of the world through the Sea by placing the missing links from state to state to involve the local governments to make sure the security of Chinese coastlines particularly the smooth navigation in South China Sea, East China Sea, and the Yellow Sea, is very critical to economic and political survival. In this regard first island Chain is significant for China as well as for America as both have associated their own interests however divergent. First Island China, which starts from South of Japan through Taiwan towards Philippines is the buffer zone for China' security while for the US it is included in the 'Defence perimeters of the US'. So, for China, it is impediment as for as China's economic and security development is concerned. To have a sustained command and control within the first island chain would ensure the China to create its own Great wall at Sea.

By erecting its own Great wall at Sea China will be in position to get its own 'offshore defence perimeters' which will allow China to operate from mainland as well as from island bases to give a pause to any hostile and foreign entry into waters. It makes it clear that how much Chinese are concerned and sensitive about their offshore defence either for defensive purpose or offensive purpose. Such level of concern has forced China to make it part of their maritime strategy at national and international level which can be seen in their Defence White papers in 2004 and onwards which makes an emphasis on increasing the capability of forces for 'winning both command of the Sea and command of the air', during 2004, it was the first time when officially such directives were announced, most emphasis was made on building up the PLA Navy equipped with new technological armaments, warships and aircrafts (Finkelstein, 2005). China's strategy for the 'Active Defence can also been traced back to Corbett's views with an ability to strike back, in form of Mao Zedong's notion of 'protracted war'. (Fravel, 2019, April 23). The capability of joint operations in a loose cohesion of services is also significant for China's stretched Seaboard. Hence, for China' Corbett's theories on maritime and land respectively, to become a power provides a positive chance to work in the context of China's peripheries of islands located in the disputed waters for conducting operations.

Holmes and Yoshihara (2010) has analyzed 'China's more emphasis is not solely on naval supremacy instead a maritime state by following the Corbett's outlines. According to them, comparison of Mahan and Corbett is gradually appearing in Chinese military assessments and evolving in Chinese military literature as 'Some Principles of Maritime Strategy' since 2008. For Chinese, only knowing Mahan is dangerous in comparison of Corbett. James Holmes and Toshi Yoshihara, Mahan and Corbett are equally significant to China as it has historic traditions of being a continental power. China' emerging naval strategy is critical at both ends either in the case of naval development or the engagement of naval fleets; a time when needed which is a true depiction of traditional maritime strategy in the context of modern warfare. Ideologically Chinese are more obsessed with their communist ideology and the great leader Mao Zedong who was scornful towards the concept of passive and assertive for active defence which is evident through his military writings in which he makes it clear that active defence is the real defence while passive is only a spurious one (Tse-tung, 1936, December).

As said by Mao, his theory of 'protracted war' has been misread as he tried to detach himself from the Western view of Chinese passive defence by giving the metaphor of 'Great Wall.' He elaborated that 'Only a complete fool or a madman,' he announced, 'would cherish passive defence as a talisman'. Instead, active defence refers to the art of preparing the conditions for 
a strategic counteroffensive culminating in a decisive engagement (Tse-tung, 1936, December). He further made it clear that there were no military or military strategists who could favour the passive defence. Sun Tzu, as his favourite strategist, also showed his priorities. Taking him into consideration, Mao used the direct and indirect attack strategies during encirclement and suppression even at domestic level during civil war and was able to take the shift of balance of power in their favour which showed an agile approach to warfare with combination of offensive and defensive tactics. Mao quoted Sun Tzu that 'avoid the enemy when he is full of vigour and attack when he is fatigued and withdraws.' Mao used a term for Chinese communist forces as 'a clever boxer' who usually gives a little ground at first, while the foolish one rushes in furiously and uses up all his resources at the very start, and in the end he is often beaten by the man who has given ground' (Tse-tung, 1936, December).

Based on the above assumptions, Mao advised the commanders 'to initiate a war at micro level offensives within a macro level defensive take a position at a strategic point where they could exhaust and drain the enemy.' He went on to affirm 'concentrate a big force to strike at a small section of the enemy force' and annihilate it, he advised. He proclaimed that' it was better to cut off one of enemy's fingers entirely than to injure them all (Tse-tung, 1936, December). Mao's approach is equally significant for the Sea and land warfare. A similar is view point is adopted by the Chinese naval strategist Ni Lexiong who has given his ideas based on the assumptions postulated by Mahan and Mao that first, Island chain is significant to keep China safe from the US hold. So offensive measures are recommended by the Chinese geostrategic to secure absolute control over the entire areas that are included in the first island chain which has been given a name by Rose and Nathan as passive Great Wall strategy that is dangerous in nature. The current maritime strategies of China are based on the combination of Mao and Mahan's notions of Sea as potential power with an ability of active defence in the form of command within waters of vital interest (Yoshihara, 2010, December) .

China's maritime strategy is based on the Sea Denial Strategy which is bound to create conditions to deter or stop the adversary from operating in a given nautical territory for a long period of time that is defensive in nature. At the same time, China is using offensive measure, tactics and techniques to execute the strategy. China is developing its forces to execute the Sea denial strategy in littoral waters along with purchasing arms from Russia since 1990s. Modern diesel submarines which are difficult to detect, armed warships with anti-ship missiles, hi tech radars are key players in pursuing this combination of approach (Holmes, 2005). These hi-tech arms are the part of Chinese military modernization effort, once they got littoral and expertise, they would be able to counter any hostile activity into is surrounding waters (Yoshihara, 2006, July/August). Currently, China is heavily dependent on installations located on mainland to combat an adversary which China is trying to shift from mainland interior lines to exterior lines. By creating an exterior point to operate, China's mainland would be in position to have more depth strategically which would help China to force its adversary to enter a combat at its own military terms and conditions, it would be same which is mentioned by Mao as the 'Boxer technique' (Adie, 1972).

The US and China both have built their capabilities in command and control, China in fact is trying to overcome its capabilities weaknesses and edge taken by the US in technological advancement and particularly the supremacy of air command which is considered a prerequisite by the analysts for surface fleet operations. According to one world view, in case of any contingency, China can deal it by blunting the US offence capability and leading its warships and fleets to more vulnerable for counterstrikes.so a vigorous approach by China to develop its 
air defence would open the horizons for offensive defence as is advised by Mao Zedong. However, China can only make it practical and challenging only by bringing all the forces on the forces to look skyward along with armed surface vessels. While according to another world view, even by developing its capabilities alone in one discipline or the combined, China would not be able to get an edge on the US particularly in littoral warfare (Khalilzad, 2001).

\section{Conclusion}

The claims on the vast part of the Sea and the development of the artificial islands to strengthen these claims and ultimately the command, testifies the relevance of Mahan's theory of the sea power as a great source of wealth. Here, a point raised by the Mahan can accurately be understood that sea is like a body, those parts which are fully and properly supplied by 'blood' of the trade are prosperous while other neglected parts remain starved, withered away, or atrophied. The states and the nations are like the human bodies particularly the maritime nations and the states which are purely dependent on the Sea borne trade and Sea communications. To obtain and maintain the export production and national prosperity such states are dependent on Sea commerce and Sea communications which can easily be hindered by the 'arterial blockage.' By reckoning the above reasons, it can be considered that even the strategic driven for, the Sea Power is not belligerent, aggressive, and offensive in nature however essentially defensive, to ensure the freedom of navigation and the uninterrupted working of the international economic system. Therefore, he intended to mention the maritime international economic system as a 'wealth-generating machine' which would result into an influential power. He projected that global trade would be more imperative in future and the international economic system would be ascertained for more vulnerable to disruption, ultimately highlighting the greater potential of the maritime trade and the Sea power.

\section{References}

Adie, W. A. (1972). Chinese strategic thinking under Mao Tse-tung. The Strategic and Defence Studies Centre. ANU Press. http://sdsc.bellschool.anu.edu.au/sites/default/files/publications/attachments/201603/sdsc-adie.pdf

Andrew Erickson, L. G. (2011, April). When land powers look seaward. Maryland. http://www.andrewerickson.com/wp-content/uploads/2011/03/erickson-goldsteinlord_when-land-powers-look-seaward_proceedings_201104.pdf

Ca, F. (2015). Demystifying China's economy development. China Social Science. https://doi.org/10.1017/CBO9781139026666

Defence Intelligence Agency, (2018, November). China military power, modernizing: a force to fight and win. Washington, D.C. United States of America. https://www.dia.mil/portals/27/documents/news/military\%20power\%20publications lchina_military_power_final_5mb_20190103.pdf

US Energy Information Administration (2018, February). China surpassed the United States as the world's largest crude oil importer in 2017. https://apps.dtic.mil/dtic/tr/fulltext/u2/1066163.pdf

David Finkelstein, E. M. (2005). Assessing China's 2004 defence white paper: a workshop. Center for Naval Analyses, CNA Corporation. https://www.cna.org/CNA_files/PDF/D0019770.A3.pdf 
Derek, W. (2015). What China has been building? The New York Times. https://www.nytimes.com/interactive/2015/07/30/world/asia/what-china-hasbeenbuilding-in-the-south-china-sea.html

Dooley, H. (2012). The great leap outward: China's maritime renaissance. The Journal of East Asian Affair, 26(1), 53-76. https://www.jstor.org/stable/23257908

Fensom, A. (2016, July). \$5 trillion meltdown: what if China shuts down the South China Sea? National Interest. http://nationalinterest.org/blog/5-trillion-meltdown-what-ifchinashuts-down-the-south-china-16996

FM 3-0 Operations. (2017, December). Washington DC: US Department of Defence. https://fas.org/irp/doddir/army/fm3-

Fravel, M. T. (April 23, 2019). Active defence: China's military strategy since 1949. Princeton University.

MI News Network (2019, October 11). Greece marks the top of most ship owning nations in 2018. $\quad$ https://www.marineinsight.com/shipping-news/greece-marks-top-shipowning-nations-2018/

Hayton, B. (2014). The South China Sea: the struggle for power in Asia. Yale University.

Hoffmann, J. (2010). The world maritime fleet in 2017. United Nations Conference on Trade and Development. UNCTAD.

Holmes, J. (2014). Defend the first Island Chain. US Naval Institute.

Holmes, J. R. (2004). Mahan a place in the Sun and Germany's quest for sea power. Comparative Strategy, 23, 27-62. https://doi.org/10.1080/01495930490274490

Holmes, T. Y. (2006). The influence of Mahan upon China's maritime strategy. Comparative Strategy 24(1), 23-51. https://doi.org/10.1080/01495930590929663

CSIS (2017, October). How much trade transits the South China Sea? https://chinapower.csis.org/much-trade-transits-south-china-sea/

Kaplan, R. (2014). Asia's Cauldron: the South China Sea and the end of a stable Pacific. Random House.

Khalilzad, Z. (2001). The United States and Asia. RAND Corporations.

King, H. J. (1990, April). The Influence of Sea Power Upon History 1660-1783. Naval War College: https://archive.org/stream/influenceofhisto00maha/influenceofhisto00maha_djvu.tx

Kurlantzick, J. (2006). China's charm: implications of Chinese soft power. Carnegie Endowment for International Peace. https://carnegieendowment.org/files/PB 47_FINAL.pdf

Lexiong, N. (2005). Sea Power and China's development. Liberation Daily.

Lexiong, N. (2007). Historical necessity for the transition from land power to sea power. World Economics and Politics.

Lloyd's List Annual Top 100 Ports. (2017, June). http://www.worldshipping.org/about-theindustry/global-trade/top-50-world-container-ports.

Mackinder. (1944). The geographical pivot of history. The Geographical Journal, 23(4), 421437.

https://is.cuni.cz/studium/predmety/index.php?do=download\&did=74431\&kod=JP M620

Mahan, A. T. (1905). The problem of Asia: its effect upon international politics. Transaction.

Mahan, A. T. (2011). The influence of sea power upon history, 1660-1783. Cambridge University.

UNCTAD (2015). Review of maritime transport. United Nations Conference on trade and development. https://unctad.org/system/files/official-document/rmt2015_en.pdf 
Robert C. Beckman et al, I. T.-G. (2013). Beyond territorial disputes in the South China Sea: legal frameworks for the joint development of hydrocarbon resources. Edward Elgar.

Sempa, F. P. (2000). Mackinder's world. American Diplomacy, V. https://americandiplomacy.web.unc.edu/

Shee Poon, K. (1998, March). The South China Sea in China's strategic thinking. Contemporary Southeast Asia, 19(4), 369-387.

Shicun $\mathrm{Wu}, \mathrm{M}$. V. (2016). UN convention on the law of the Sea and the South China Sea. Routledge.

Sou, Y. h. S. (Ed.). (2015, July). Major law and policy issues in the South China Sea: European and American Perspectives. Ashgate.

Sprout, M. T. (n.d.). 'Mahan: evangelist of sea power.' In Makers of Modern Strategy: Military Thought from Machiavelli to Hitler. Princeton.

Tønnesson, S. (2015, June). The South China Sea: law trumps power. Asian Survey, 55(3), 455-477. https://www.jstor.org/stable/10.1525/as.2015.55.issue-3

Tse-tung, M. (1936, December). Problems of strategy in China's revolutionary war. Selected Works of Mao Tse-tung, Maoist Documentation Project. https://www.marxists.org/reference/archive/mao/selected-works/volume-

Tung, C. Y. (2005, September). Overview of Chinese Economic Reforms: Initiatives, Approaches and Consequences. National Chengchi University, Taiwan.

Ünay, S. (2013). From engagement to contention: China in the global political economy. Perceptions, $\quad$ XVIII(1), 129-153. $\quad$ http://www.sam.gov.tr/wpcontent/uploads/2013/07/perceptions_2013_spring.pdf\#page $=133$

Yoshihara, J. H. (2006, July/August). Mao Zedong, meet Alfred Thayer Mahan: strategic theory and Chinese sea power. Australian Defence Force Journal, 171. https://search.informit.com.au/documentSummary;dn=200700786;res=IELAPA, ISSN: 1320-2545

Yoshihara, J. H. (2010, December). China's navy: a turn to Corbett? Maryland: The United States Naval Institute. https://www.usni.org/magazines/proceedings/2010/december/chinas-navy-turn$\underline{\text { corbett }}$ 